\title{
The role of emotional intelligence and autonomy in transformational leadership: A leader member exchange perspective
}

\begin{tabular}{|c|c|}
\hline \multicolumn{2}{|c|}{$\begin{array}{l}\text { Authors: } \\
\text { Maryam Waglay }{ }^{1} \text { (D) } \\
\text { Jurgen R. Becker }{ }^{1} \text { (D) } \\
\text { Marieta du Plessis }{ }^{1}\end{array}$} \\
\hline \multicolumn{2}{|c|}{$\begin{array}{l}\text { Affiliations: } \\
{ }^{1} \text { Department of Industrial } \\
\text { Psychology, Faculty of } \\
\text { Economic and Management } \\
\text { Sciences, University of the } \\
\text { Western Cape, Cape Town, } \\
\text { South Africa }\end{array}$} \\
\hline \multicolumn{2}{|c|}{$\begin{array}{l}\text { Corresponding author: } \\
\text { Jurgen Becker, } \\
\text { jbecker@uwc.ac.za }\end{array}$} \\
\hline \multicolumn{2}{|c|}{$\begin{array}{l}\text { Dates: } \\
\text { Received: } 16 \text { Nov. } 2019 \\
\text { Accepted: } 26 \text { Feb. } 2020 \\
\text { Published: } 30 \text { Apr. } 2020\end{array}$} \\
\hline \multicolumn{2}{|c|}{$\begin{array}{l}\text { How to cite this article: } \\
\text { Waglay, M., Becker, J.R., \& } \\
\text { Du Plessis, M. (2020). The role } \\
\text { of emotional intelligence and } \\
\text { autonomy in transformational } \\
\text { leadership: A leader member } \\
\text { exchange perspective. SA } \\
\text { Journal of Industrial } \\
\text { Psychology/SA Tydskrif vir } \\
\text { Bedryfsielkunde, } 46(0) \text {, a1762. } \\
\text { https://doi.org/10.4102/sajip. } \\
\text { v46i0.1762 }\end{array}$} \\
\hline \multicolumn{2}{|c|}{$\begin{array}{l}\text { Copyright: } \\
\text { (C) 2020. The Authors. } \\
\text { Licensee: AOSIS. This } \\
\text { is licensed under the } \\
\text { Creative Commons } \\
\text { Attribution License. }\end{array}$} \\
\hline \multicolumn{2}{|l|}{ Read online: } \\
\hline 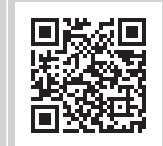 & $\begin{array}{l}\text { Scan this QR } \\
\text { code with your } \\
\text { smart phone or } \\
\text { mobile device } \\
\text { to read online. }\end{array}$ \\
\hline
\end{tabular}

Orientation: The role of emotional intelligence, autonomy and leader member exchange (LMX) is examined in the relationship between transformational leadership and unit-level performance.

Research purpose: The goal of the present study was to investigate the role of emotional intelligence and autonomy in the effectiveness of leadership in organisations through high LMX relationships.

Motivation for the study: The relationship between transformational leadership and unitlevel performance is well documented. However, the specific role of emotional intelligence, job autonomy and high-quality LMX relationships as transmission mechanisms is not well understood.

Research approach/design and method: The study used an ex post facto research design and a convenience sampling approach. A sample of employees working as managers $(n=226)$ in a large financial institution in South Africa participated in the study. The proposed conceptual model was empirically tested by means of simple and hierarchical regression analyses.

Main findings: The results suggest that transformational leadership is effective in driving follower performance through emotional intelligence and strong LMX relationships. Furthermore, LMX and emotional intelligence fully mediate the relationship between transformational leadership and job performance.

Practical/managerial implications: The effectiveness of transformational leaders can be explained through the strong LMX relationships that they develop with followers by using emotional intelligence as an influencing strategy.

Contribution/value-add: The study aims to explain the primary mechanism through which transformational leaders encourage job performance and high unit-level performance. The results indicate emotional intelligence as an important mechanism used by transformational leaders to build strong teams, which ultimately results in highperforming teams.

Keywords: transformational leadership; leader member exchange (LMX); emotional intelligence; job performance; job characteristics; autonomy.

\section{Introduction}

Transformational leadership is often regarded as the leadership style that is most effective in building team morale and high follower performance. Bass (1990) explained that transformational leaders:

$[B]$ roaden and elevate the interests of their employees, when they generate awareness and acceptance of the purposes and mission of the group, and when they stir their employees to look beyond their own selfinterest for the good of the group. (p. 21)

Although the link between transformational leadership and follower performance is well established in literature, much less is understood about the psychological mechanisms that take place in the social interaction between the leader and the followers. For this reason, the social exchange in the reciprocal relationship lies at the heart of transformational leadership theory and team effectiveness (Li \& Hung, 2009). 
Recently, scholars started paying more attention to the dynamic formation of work relationships and trust between leaders and followers rather than the innate traits of leaders. There are numerous variables that can influence leadership effectiveness and performance (Alabi \& Alabi, 2014). However, few of these attributes have been linked to the effective social exchanges that take place between leaders and followers. The current study argues that emotional intelligence is not always universally researched or acknowledged as a key attribute used by leaders to understand and gauge followers' emotions. In this study, it is argued that emotional intelligence is a key ingredient in the formation of high-quality leader member exchange (LMX) relationships.

In addition to the quality of the social exchange relationship, it is argued that contextual factors have an impact on the link between job performance and LMX. For this reason, autonomy has been included as a key variable along with emotional intelligence to explain the nomological network of relationships between transformational leadership, LMX and job performance.

\section{Literature review Theoretical framework}

The role-making process between transformational leaders and followers has been investigated by means of social exchange theory. The theory states that leaders and members interact with one another in a dyadic relationship, where the leader affects the follower and the follower affects the leader (Northouse, 2016). The vertical dyadic linkages between leaders and followers moved the emphasis away from the innate traits of the leaders and focussed on the quality of the relationship between leaders and followers. Today, LMX theory is probably the most common and well-known of the dyadic relationship theories.

\section{Transformational leadership and job performance}

The trait-based perspective on leadership has dominated the leadership literature since the seminal studies of Bass and Avolio (1993). Transformational leadership, in particular, has been a significant field of inquiry in organisational psychology and has attracted voluminous research because of its strong and consistent link with high-performing teams (Gardner, Lowe, Moss, Mahoney, \& Collier, 2010; Lowe \& Gardner, 2001). Bass (1985) conceptualised a simple yet powerful theory of leadership by integrating transformational, transactional and laissez-fair leadership styles into a single theory. In short, the theory argues that transformational leaders build strong teams by appealing to the psychological needs of followers. Accordingly, transformational leaders make use of a combination of influence strategies, which can be summarised as inspirational motivation, intellectual stimulation, individualised consideration and idealised influence. These four strategies are often referred to as the four I's. Meta-analyses consistently support the link between transformational leadership and follower performance (Wang, Oh, Courtright, \& Colbert, 2011), and for this reason a strong positive association is expected between transformational leadership and unit-level performance:

H1: There is a positive relationship between transformational leadership and job performance.

In contrast, transactional leaders mainly utilise goal-setting theory to achieve organisational goals by monitoring and controlling outcomes (Aga, 2016). Although strong links are often reported between transactional leadership styles and unit-level performance, the relationship is often built on incentives rather than social exchanges of mutual benefit between leaders and followers (Bass, 1985). Given that both leadership styles have strong links to unitlevel performance, significant research attention has been dedicated to the psychological mechanism between leaders and followers.

\section{Leader member exchange theory}

The theory advocates that a dyadic relationship exists between a leader and a follower and that leaders treat individual followers differently (Krishnan, 2005). The result is two groups of followers, one being the in-group and the other, the out-group. Because of the nature of the relationship, some followers would be part of the in-group and not the others (Dansereau, Graen, \& Haga, 1975). This in-group has a different 'high-quality exchange relationship', whereas the out-group has a 'more formal' relationship with the leader (Krishnan, 2005). Dienesch and Liden (1986) observed the results of individuals with high-quality relationships with the leader and having a greater reciprocal relationship as well as open communication and respect between each other. The level of mutual dependence that is created over time leads to an expectation of commitment to task objectives, and the leader, on the other hand, must maintain that relationship. Given the strong theoretical links between the transformational leadership theory and LMX theory, transformational leadership can be described as the operative form of LMX (Graen \& Uhl-bien, 1995). Furthermore, the two-way relationship between transformational leadership and LMX has a spillover effect on job follower performance (Cheung, Connelly, Jiang, \& Limpaphayom, 2011):

H2: There is a positive relationship between transformational leadership and LMX.

H3: The relationship between transformational leadership and follower performance is mediated by LMX.

\section{Emotional intelligence}

Given the strong emotional attachment leaders foster with employees with high LMX relationships, many authors have argued that emotional intelligence is an important personal attribute of transformational leaders (Welch, 2003). As social exchanges play a central role in the dyadic relationship between leaders and their followers, the importance of 
emotional regulation and intelligence has been a popular topic of investigation.

Similar to the broader concept of intelligence, emotional intelligence has been described as follows (Mayer \& Salovey, 1997):

[T]he ability to perceive accurately, appraise, and express emotion; the ability to access and/or generate feelings when they facilitate thought; the ability to understand emotion and emotional knowledge; and the ability to regulate emotions to promote emotional and intellectual growth. (p. 10)

The original conceptualisation of Bass' theory argues that the biggest difference between the transactional and transformational leader is the emotional attachment of transformational leaders with followers (Bass, 1985).

Fundamentally, it can be argued that the transformational leader is more effective than the transactional leaders because of their concern for their followers through applying higher levels of emotional intelligence could result in a higherquality LMX relationship. Goleman (2001) argued that emotional intelligence is the core of effective leaders. When the four I's of transformational leadership are considered in relation to emotional intelligence characteristics, it becomes apparent that there is a conceptual overlap between the two concepts. Bass (1985) recognised the difference between transactional leader and the transformational leader, where leaders are less controlling but more inclined towards nurturing a relationship between the leader and followers. This in turn allows the transformational leader to be more effective in driving results than the typical manager who may not display a high level of emotional intelligence in the workplace (Ducket \& Macfarlane, 2003). Thus, one would expect emotional intelligence to mediate the development of higher-quality LMX relationships:

H4: There is a positive relationship between transformational leadership and emotional intelligence.

H5: The relationship between transformational leadership and LMX is mediated by emotional intelligence.

H6: There is a positive relationship between emotional intelligence and job performance.

However, the effectiveness of any leader is somewhat dependent on the general context in which the dyadic relationship is established and maintained (Jiang, Zhao, \& $\mathrm{Ni}, 2017)$. By using the four main influencing strategies, transformational leaders are able to build relationships with followers based on trust. Thus, transformational leaders build an enabling environment by focussing on the emotional needs of followers. This in turn should lead to higher levels of performance (George, 2000). Based on the foregoing, it is expected that the relationship between transformational leadership and follower performance is mediated by emotional intelligence:

H7: The relationship between transformational leadership and job performance is mediated by emotional intelligence.
H8: There is a positive relationship between LMX and job performance.

\section{Autonomy}

Hackman and Oldham (1975) indicated that job characteristics may influence the motivation of workers. For this reason, it is important to consider the impact of job characteristics alongside innate personal attributes of the leader and followers. According to their model, five core characteristics drive the motivational potential of any job. These five core job characteristics are skill variety, task identity, task significance, autonomy and feedback.

In the context of the LMX and transformational leadership, job characteristics are likely to moderate the relationship (Dunegan, Uhl-Bien, \& Duchon, 2002).

Although there is a myriad of different job characteristics that may moderate the relationship between transformational leadership and job performance, the literature suggests that autonomy may be particularly potent because of its association with transformational leadership. Job autonomy refers to the discretion and independence in determining the procedure of how work will be performed (Hackman \& Lawler, 1971, p. 265).

According to Cleavenger and Munyon (2013), if personal development is considered important for the employee, then job autonomy will serve as a measure of how the job will be performed. The inspiring leader fosters a sense of responsibility and agency of followers by allowing them to be their own leaders (Yammarino, 1994).

In a study on the moderating effects of LMX and job performance by Kim, Liu and Diefendorff (2015), it was found that leaders differentiate amongst employees. If the quality of the LMX relationship is high, leaders may assign higher levels of responsibility and autonomy to followers. However, if the LMX relationship is low, leadership may be less reluctant to empower followers because of the inherent distrust in the relationship. This results in different types of exchange relationships (Liden, Sparrowe, \& Wayne, 1997) and that the level of exchange attributes to a sense of psychological empowerment ultimately result in improved job performance (Kim et al., 2015):

H9: There is a positive relationship between LMX and autonomy.

H10: The relationship between LMX and job performance is moderated by autonomy.

H11: There is a positive relationship between transformational leadership and autonomy.

\section{Proposed conceptual model}

The arguments presented in the foregoing section resulted in a complex model containing direct, indirect and mediating effects. More specifically, the hypothesising was directed at presenting a complex yet coherent theoretical model which 
aims to explain unit performance in the workplace. Building on the work of previous authors, it is argued in this study that the clear link between transformational leadership and job performance may have been presented too simplistically. The network of indirect and mediating variables that shape individual performance in the workplace may start with transformational leadership behaviours, but then follows a sequential mediating model through LMX and emotional intelligence before resulting in job or unit performance.

The proposed sequential model may be moderated by autonomy in the final link between LMX and job performance. In addition to the mediating effects, transformational leadership is expected to have additional direct effects on job performance and autonomy. The proposed model is graphically depicted in Figure 1.

\section{Research design}

\section{Research approach}

In the present study, a quantitative research approach was adopted in which standardised measures were used to collect data. An ex post facto research design was used to empirically validate the research hypotheses. The researchers made use of convenience sampling and as such findings from the current study cannot be reasonably generalised to the rest of the population. A convenience sampling approach was used because the researchers did not have access to the large population of mid-level managers working in the banking sector in South Africa.

\section{Research method \\ Participants and sampling}

In total 226 participants completed the questionnaires. The population for this research project consisted of managers and employees at an international banking institution. The target population included leaders (supervisors, $n=60$ ) in supervisory or managerial positions, as well as followers (supervisees, $n=166$ ). The biographical characteristics of the sample included age, gender, educational level, years of service, type of employment and job level. The characteristics of the sample are summarised in Table 1.

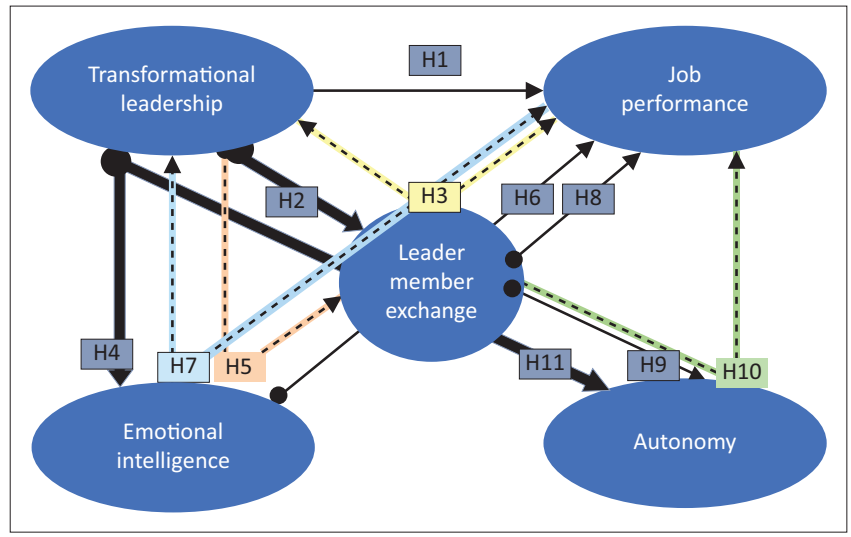

$\mathrm{H}$, hypothesis.

FIGURE 1: Conceptual model.
TABLE 1: Demographic characteristics of participants.

\begin{tabular}{llcc}
\hline Variable & Category & $\begin{array}{c}\text { Frequency of } \\
\text { participants }\end{array}$ & $\begin{array}{c}\text { \% of the } \\
\text { participants }\end{array}$ \\
\hline Gender & Male & 55 & 24.3 \\
& Female & 169 & 74.8 \\
Ethnicity & Missing & 2 & 0.9 \\
& Black people & 20 & 8.8 \\
& Mixed race people & 101 & 44.7 \\
& Indian people & 3 & 1.3 \\
& White people & 94 & 41.6 \\
& Other & 6 & 2.7 \\
& Missing & 2 & 0.9 \\
Highest level of education & Grade 12 & 51 & 22.6 \\
& Diploma & 59 & 26.1 \\
& Bachelor's degree & 24 & 10.6 \\
& Honours & 15 & 6.6 \\
& Masters & 4 & 1.8 \\
& Other & 6 & 2.7 \\
& Missing & 3 & 1.3 \\
\hline
\end{tabular}

\section{Data collection procedure and ethical consideration}

An email link to the survey was sent to supervisors and supervisees for which performance data were available on the business unit level. In total five business units participated in the study. The email contained information about the study and provided information regarding the rights of research participants. Participants could continue completing the questionnaire only if they provided consent.

All the results were anonymised by encrypting the data by the partnering organisation. It was not possible for the researchers to identify any of the research participants. Every effort was taken to protect the privacy and maintain confidentiality of the information acquired from the participation in the study. Participants were also informed that they could withdraw their participation at any moment without fear of sanction.

\section{Measuring instruments}

In addition to the biographical section, four questionnaires were chosen to measure the latent variables included in the conceptual model. The Genos short version was used to measure emotional intelligence, the LMX-7 Questionnaire was used to measure LMX, the Multifactor Leadership Questionnaire (MLQ) was used to measure transformational leadership and the Work Design Questionnaire (WDQ) was used to measure job autonomy.

\section{Unit-level performance}

Unit-level performance data were provided by the organisation for each business unit. The partnering organisation linked the unit-level performance scores to each respondent before encrypting the data. In total, performance data were provided for five business units. Performance was measured across six performance categories using a six-point rating scale. The rating scale consisted of the following scale points: underperforming, improvement needed, good, strong, very strong and outstanding. Scores across the six 
performance areas were aggregated by means of an equally weighted arithmetic mean calculation to arrive at a total score. Individual scores were aggregated to form business unit scores. Thus, all individuals in a given business unit received the same score.

The performance rating was based on supervisory ratings for the last four quarters in the organisation. The performance rating is used for developmental and promotion purposes in the organisation and is generally carried out each quarter by direct supervisors.

\section{The Genos emotional intelligence inventory (short)}

The short version of the Genos emotional intelligence inventory has been designed to measure the frequency of demonstrating emotional intelligence behaviours in the work setting (Palmer \& Stough, 2001). It has since been widely used in a wide variety of settings. Participants indicate their level of agreement on a five-point Likert-type scale ranging between 1 = Almost Never, 2 = Seldom, 3 = Sometimes, $4=$ Usually and $5=$ Almost Always. The scale consists of 14 items and typically takes between 2 and $5 \mathrm{~min}$ to complete. For example, a typical item would be 'I consider the way others may react to decisions when communicating them'.

As for the validity and reliability of this measure, Gignac (2008) stated that the mean subscale reliabilities ranged from 0.71 to 0.85 across five nationalities (American, Australian, Asian, Indian and South African). The mean Genos emotional intelligence total score internal consistency reliability was estimated at 0.96 . Furthermore, the test-retest reliability found test-retest correlations of 0.83 and 0.72 based on 2-month and 6-month time intervals for Genos emotional intelligence total scores, respectively.

\section{The multifactor leadership questionnaire}

The MLQ was originally developed by Bass and Avolio (1992), and the shortened form (MLQ-6-S) was further refined by Northouse (2001). The MLQ-6-S is a self-report questionnaire consisting of 21 items and is measured on a five-point Likert-type scale $(0=$ not at all, $4=$ frequently, if not always) measuring three leadership styles. The MLQ-6S was developed to measure transformational, transactional and laissez-faire leadership styles.

The MLQ is arguably the most widely used tool to assess transactional and transformational leadership (Kirkbride, 2006). Pillay, Viviers and Mayer (2013) tested the internal consistency of the MLQ in a large petrochemical organisation in South Africa and found that the Cronbach's coefficient alpha of 0.87 for the transformational leadership dimension. Given the large body of literature confirming the reliability and validity of the MLQ, the authors felt confident in using the measure in the South African context. An example of a typical item in the MLQ is 'I enable others to think about old problems in new ways'.

\section{Work design questionnaire}

The WDQ was developed by Morgeson and Humphrey (2006) measuring 21 work characteristics grouped into four higher-order categories, namely task, knowledge, social and contextual characteristics. The instrument consists of 72 items on a five-point Likert-type scale, which measures 14 work design variables and two outcome variables. Participants indicate their degree to which they agree with statements on a scale ranging from 1 = 'strongly disagree' to $5=$ 'strongly agree'. The WDQ scales demonstrate high internal consistency reliability across the dimensions within an average Cronbach's coefficient alpha of 0.87 across a multitude of studies (Morgeson \& Humphrey, 2006).

\section{Leader member exchange questionnaire}

The LMX-7 short form was developed by Graen and UhlBien in 1995. The LMX-7 scale calculates the degree to which leaders and followers have a sense of mutual trust or obligation to each other. Respondents indicate their degree of endorsement of each item on a five-point rating scale. The score obtained on the questionnaire is indicative of the quality of the relationship. In a study by Maslyn and UhlBien (2001) in a large service organisation of relationship development, the LMX-7 questionnaire was found to have an internal consistency reliability alpha of 0.92 , and the findings indicated how relationships developed and provided practical implications of the study. The LMX-7 has been used across a wide variety of context and consistently demonstrates strong reliability and validity (Setley, Dion, \& Miller, 2013).

\section{Statistical analysis}

The aim of this study was to validate the relationships captured in the proposed theoretical model. Data analysis was conducted using the Statistical Package for the Social Sciences (SPSS version 25, 2017).

The first step in the data analyses process was to evaluate the data for typing errors, out of range responses and outliers. This was conducted by means of descriptive statistics. The second step was to evaluate the skewness and kurtosis of the data by means of box-and-whisker plots and descriptive statistics. Skewness of variables was assessed by dividing the skewness score by its associated standard error. If the results are greater than \pm 1.96 , it suggests that the data are not normal with respect to this specific statistic (Rose, Spinks, \& Canhoto, 2015). The third step was to assess the construct validity and internal consistency reliability of each measure used in the study. Although the primary aim of the study was not to evaluate the reliability and validity of the instruments, this remains a critical first step prior to conducting the regression analyses. In the absence of construct validity and reliability, the relationships between variables will remain ambiguous (Cronbach, 1951).

For this reason, it was decided to test the dimensionality of the measure through exploratory factor analysis (EFA, 
maximum likelihood estimator with Promax rotations) and internal consistency by means of Cronbach's coefficient alpha. Finally, the proposed moderator, mediator and direct relationships were measured by means of regression analyses.

The three-step approach to test mediation by Baron and Kenny (1986) was used to test the statistical significance of the indirect effects. According to Hood, Conlon and Andrews (2008), mediation analysis can be described as a method used to determine the degree to which indirect paths via the mediator explain the association between the independent variable and the dependent variable (Baron \& Kenny, 1986; Kenny, Kashy, \& Bolger, 1998; Shrout \& Bolger, 2002).

Three basic conditions need to exist for mediation:

- The predictor must be able to explain significant variation in the hypothesised mediator, which is path a.

- The mediator must account for significant variation of the criterion in path $b$.

- When steps 1 and 2 of the analysis are satisfied, a previously significant relationship between the predictor and criterion (path c) will result in nonsignificance (complete mediation) or substantially reduced significance (partial mediation).

This will provide the coefficient, indicating the mediating effect amongst the dependent (criterion) and independent variables (predictors) (Hood et al., 2008).

\section{Results}

The SPSS descriptive statistics were used to investigate the distribution of scores. More specifically $z$-scores greater than 3 were regarded as outliers (Tabachnick \& Fidell, 2007). Descriptive statistics were also used to investigate the skewness and kurtosis of observed indicator variables. The significance of skewness and kurtosis can be evaluated by dividing the estimated values by their corresponding standard errors (Tabachnick \& Fidell, 2007).

From Table 2, we can see that none of the combined variables seem to be overtly skew; however, the box-and-whisker plot in Figure 2 indicates that job performance and MLQ were not normally distributed.

Subsequently, the dimensionality of the measures was evaluated by means of EFA. In the current study, the maximum likelihood estimator with Promax rotations was selected. Table 3 indicates the number of items in each factor, the range of factor loadings and the percentage common

TABLE 2: Skewness and kurtosis of the variables.

\begin{tabular}{lccc}
\hline Measure & SD & Skewness & Kurtosis \\
\hline MLQ & 2.56 & 0.38 & -0.87 \\
LMX & 3.34 & 1.04 & -0.43 \\
EI & 3.79 & 0.36 & -1.23 \\
AUT & 3.50 & 0.72 & -0.79 \\
JP & 3.76 & 0.24 & -6.18 \\
\hline
\end{tabular}

$M L Q$, multifactor leadership questionnaire; LMX, leader member exchange; El, emotional intelligence; AUT, autonomy; JP, job performance; SD, standard deviation.

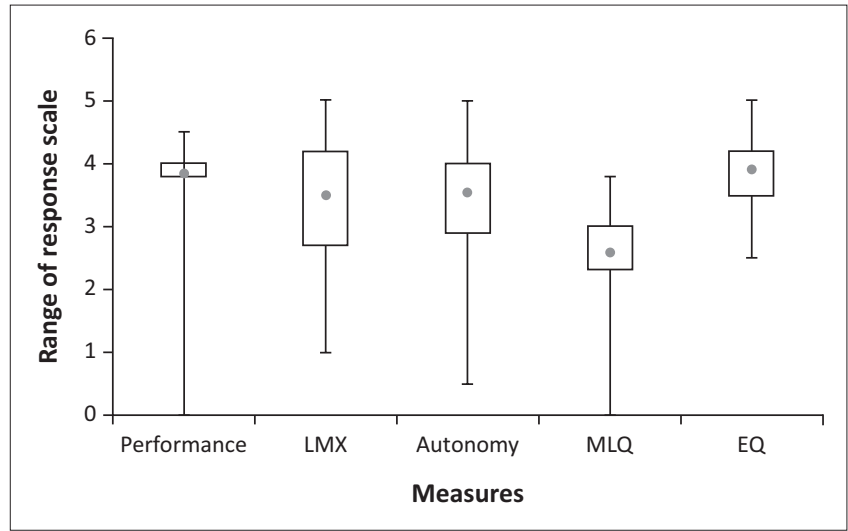

LMX, leader member exchange; MLQ, multifactor leadership questionnaire; $E Q$, emotiona intelligence.

FIGURE 2: Box and whisker plot indicating distribution of factor scores for each measure.

variance explained by the primary factor. No items were deleted from the factors and all items loaded on a single prominent factor.

Unidimensionality is an important prerequisite for internal consistency reliability. Considering that all four measures can be regarded as unidimensional, the 'Testing the direct effects' section will consider the internal consistency of all four measures utilised in the study. Results from the internal consistency reliability are described in Table 4.

Results from the reliability analyses suggest that the measures used in the current investigation can be regarded as internally consistent. The total correlations of all the items were high, and no items would lead to an increase in Cronbach's alpha when deleted.

Evidence presented in 'Statistical analysis' section indicates that the measures used in the current study are both unidimensional and have internal consistency and for this reason can be combined into a single factor score.

\section{Testing the direct effects}

The literature review culminated into the conceptualisation of a model with numerous direct, indirect and mediating relationships. The results will be discussed by first examining the direct effects followed by the indirect effects and mediation results in 'Testing the mediated and moderated effects' section. The main effects in the model are depicted as a graphical model in Figure 3.

The theoretical model conceptualised in the current study was operationalised and empirically tested by way of regression analyses. The results of the regression analyses are summarised in Table 5 .

Looking at the results shown in Table 5, one can see empirical support was found for the proposed relationship between transformational leadership and job performance. The results $\left(\mathrm{H}_{1}, \beta_{\mathrm{MLQ}}=0.13\right)$ indicate that transformational leadership explains $1.8 \%$ of the variation in job performance. 
On the other hand, transformational leadership has a significant positive relationship with $\mathrm{LMX}\left(\mathrm{H}_{2}, \mathrm{R}^{2}=0.03\right.$, $\left.F=5.75^{*}\right)$, emotional intelligence $\left(\mathrm{H}_{4}, R^{2}=0.24, F=70.79 * *\right)$ and autonomy $\left(\mathrm{H}_{11}, R^{2}=0.02, F=4.59 *\right)$. From Table 5, emotional intelligence shows a significant positive relationship with job performance $\left(\mathrm{H}_{6} R^{2}=0.05, F=13.93^{* *}\right)$ and a significant positive relationship with LMX and job performance $\left(\mathrm{H}_{8}, R^{2}=0.03, F=6.20^{*}\right)$. Lastly, Hypothesis 9 indicates that LMX shows a significant positive relationship with autonomy $\left(R^{2}=0.19, F=51.53^{* *}\right)$.

In summary, the results establish multi-relationships with transformational leadership being a significant predictor for LMX, emotional intelligence, autonomy and job performance. However, from the $R^{2}$ values, we can see transformational

TABLE 3: Sample adequacy for performing exploratory factor analysis.

\begin{tabular}{lcccc}
\hline Subscale & $\begin{array}{c}\text { Number of } \\
\text { items }\end{array}$ & $\begin{array}{c}\text { Range of factor } \\
\text { loadings }\end{array}$ & $\begin{array}{c}\text { Approximate } \\
\text { chi-square }\end{array}$ & $\begin{array}{c}\text { Common } \\
\text { variance (\%) }\end{array}$ \\
\hline EI & 14 & $0.32-0.63$ & 623.927 & 20.8 \\
LMX & 7 & $0.69-0.87$ & 1108.761 & 63.7 \\
MLQ & 12 & $0.50-0.77$ & 2271.443 & 45.3 \\
AUT & 9 & $0.79-0.88$ & 1670.748 & 72.1 \\
\hline
\end{tabular}

MLQ, multifactor leadership questionnaire; LMX, leader member exchange; El, emotional intelligence; AUT, autonomy.

TABLE 4: Cronbach's alpha results on sections of the questionnaire.

\begin{tabular}{lcccc}
\hline Subscale & Number of items & Cronbach's alpha & Mean & SD \\
\hline EI & 14 & 0.75 & 50 & 6.97 \\
LMX & 7 & 0.92 & 23.6 & 6.93 \\
MLQ & 12 & 0.90 & 54.2 & 9.36 \\
AUT & 9 & 0.95 & 30.7 & 8.61 \\
\hline
\end{tabular}

El, emotional intelligence; $L M X$, leader member exchange; MLQ, multifactor leadership questionnaire; AUT, autonomy; SD, standard deviation.

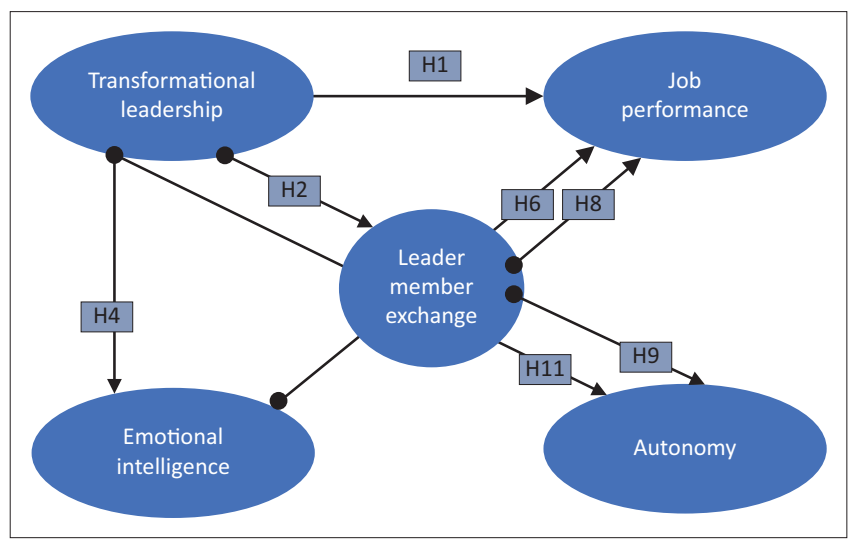

$\mathrm{H}$, hypothesis.

FIGURE 3: Direct effects of mediation. leadership explains about a quarter of the total variance in emotional intelligence and about $1.8 \%$ of the total variance in job performance.

\section{Testing the mediated and moderated effects}

The mediated and moderated relationships proposed in the conceptual model are depicted in Figure 4.

The three-step approach of Baron and Kenny (1986) was used to test the mediator effects depicted in Figure 4 . The results of hypotheses 3, 5 and 7 are depicted in Table 6.

Hypothesis 3 predicted that the relationship between transformational leadership and job performance is mediated by LMX. The results from the regression analysis are depicted in Table 6.

For Hypothesis 3, the direct relationship between transformational leadership and job performance was significant (step 1). After the mediation term was entered into the equation, the relationship between transformational leadership and job performance was non-significant. The relationship between transformational leadership and job performance may be regarded as fully mediated because this relationship changed from a statistically significant relationship in step $1\left(\beta_{\mathrm{MLQ}}=0.133, p<0.05\right)$ to a non-significant relationship in step 2 when the mediator variable LMX was included in the multiple regression equation $\left(\beta_{\mathrm{MLQ}}=0.11\right.$, $p<0.104)$. This indicates that empirical support was found for Hypothesis 3 and the relationship between leadership

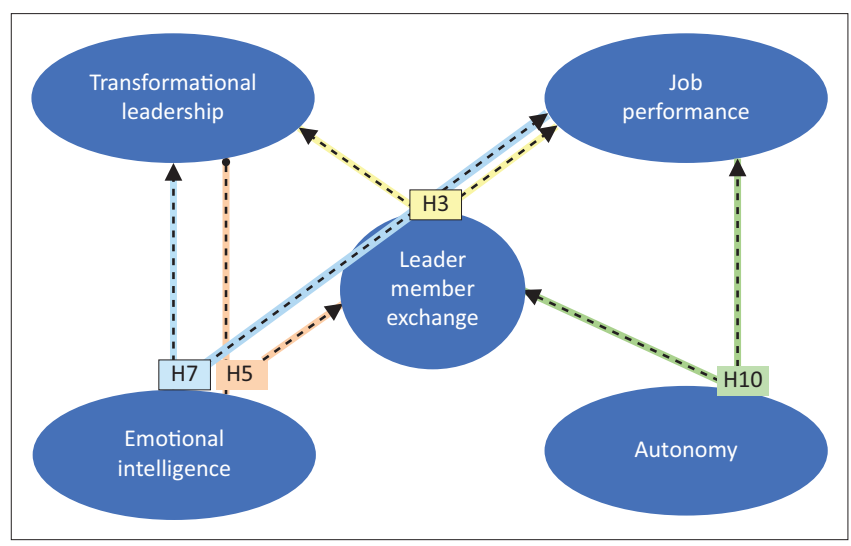

$\mathrm{H}$, hypothesis.

FIGURE 4: Mediated and moderated relationships.

TABLE 5: Results from regression analyses: Direct effects.

\begin{tabular}{|c|c|c|c|}
\hline Hypothesis & Standardised beta value $\left(\beta_{\mathrm{MLQ}}\right)$ & $R^{2}$ & $\boldsymbol{F}$ \\
\hline 1: There is a positive relationship between transformational leadership and job performance. & $0.133^{*}$ & 0.018 & 3.96 \\
\hline 2: There is a positive relationship between transformational leadership and LMX. & $0.16^{*}$ & 0.03 & $5.75 *$ \\
\hline 4: There is a positive relationship between transformational leadership and emotional intelligence. & $0.49 * *$ & 0.24 & $70.79 * *$ \\
\hline 6: There is a positive relationship between emotional intelligence and job performance. & $0.24 * *$ & 0.05 & $13.93 * *$ \\
\hline 8: There is a positive relationship between LMX and job performance. & $0.17 *$ & 0.03 & $6.20 *$ \\
\hline 9: There is a positive relationship between LMX and autonomy. & $0.43 * *$ & 0.19 & $51.53 * *$ \\
\hline 11: There is a positive relationship between transformational leadership and autonomy. & $0.14 *$ & 0.02 & $4.59 *$ \\
\hline
\end{tabular}


TABLE 6: Mediation analysis.

\begin{tabular}{|c|c|c|c|c|c|c|c|}
\hline Hypothesis & Testing paths & Unstandardised beta & Standard error (SE $\beta$ ) & Standardised beta $(\boldsymbol{\beta})$ & $R^{2}$ & $F$ & $p$ \\
\hline \multirow{8}{*}{$\begin{array}{l}\text { Hypothesis 3: The } \\
\text { relationship between } \\
\text { transformational } \\
\text { leadership and follower } \\
\text { performance is } \\
\text { mediated by LMX. }\end{array}$} & Path c DV = Job performance & & & & 0.02 & 3.97 & $<0.05$ \\
\hline & IV: Transformational Leadership & 0.05 & 0.03 & $0.13^{*}$ & & & \\
\hline & Path a DV: Leader member exchange & & & & 0.03 & 5.75 & $<0.05$ \\
\hline & IV = Transformational Leadership & 0.27 & 0.11 & $0.16^{*}$ & & & \\
\hline & Path $b$ and $c^{\prime} D V=$ Job performance & & & & 0.04 & 4.44 & $<0.05$ \\
\hline & IV: (c) & 0.04 & 0.03 & 0.11 & & & \\
\hline & IV: (b) & 0.03 & 0.01 & $0.15^{*}$ & & & \\
\hline & Total $(a) *(b)$ & - & - & $0.024 *$ & & & \\
\hline \multirow{7}{*}{$\begin{array}{l}\text { Hypothesis } 5: \text { The } \\
\text { relationship between } \\
\text { transformational } \\
\text { leadership and LMX is } \\
\text { mediated by emotional } \\
\text { intelligence. }\end{array}$} & Path c DV = Leader member exchange & & & & 0.03 & 5.75 & $<0.031$ \\
\hline & IV: Transformational Leadership & 0.27 & 0.11 & $0.16^{*}$ & & & \\
\hline & Path a DV: Emotional intelligence & & & & 0.24 & 70.49 & $<0.001$ \\
\hline & IV = Transformational Leadership & 0.44 & 0.05 & $0.49 * *$ & & & \\
\hline & Path $b$ and $c^{\prime} D V=$ Leader member ex & xchange & & & 0.05 & 5.93 & $<0.01$ \\
\hline & $\mathrm{IV}:(\mathrm{c})$ & 0.12 & 0.13 & 0.07 & & & \\
\hline & Total $(a) *(b)$ & - & - & $0.08^{*}$ & & & \\
\hline \multirow{8}{*}{$\begin{array}{l}\text { Hypothesis 7: The } \\
\text { relationship between } \\
\text { transformational } \\
\text { leadership and job } \\
\text { performance is } \\
\text { mediated by emotional } \\
\text { intelligence. }\end{array}$} & Path c DV = Job Performance & & & & 0.13 & 3.97 & $<0.05$ \\
\hline & IV: Transformational Leadership & 0.05 & 0.02 & $0.13^{*}$ & & & \\
\hline & Path a DV: Emotional intelligence & & & & 0.21 & 70.48 & $<0.001$ \\
\hline & IV = Transformational Leadership & 0.45 & 0.06 & $0.49 * *$ & & & \\
\hline & Path $b$ and $c^{\prime}$ DV = Job performance & & & & 0.06 & 6.91 & $<0.01$ \\
\hline & IV: (c) & 0.00 & 0.03 & 0.02 & & & \\
\hline & IV: (b) & 0.10 & 0.03 & $0.25 *$ & & & \\
\hline & Total $(a) *(b)$ & - & - & $0.12 *$ & & & \\
\hline
\end{tabular}

$\mathrm{SE}$, standard error; $\mathrm{DV}$, dependent variable; IV, independent variable; $R^{2}$, coefficient of determination; $\mathrm{LMX}$, leader member exchange.

$*, p \leq 0.05 ; * *, p \leq 0.001$.

TABLE 7: Results of the moderated regression analyses.

\begin{tabular}{|c|c|c|c|c|c|c|}
\hline \multirow[t]{3}{*}{ Hypothesis } & \multicolumn{2}{|c|}{ Beta value and statistical significance } & \multicolumn{4}{|c|}{$R^{2}$ value and $F$-test } \\
\hline & \multirow[t]{2}{*}[\mathrm{A}]{$\boldsymbol{\beta}_{\mathrm{LMX}}$} & \multirow[t]{2}{*}[\mathrm{B}]{$\boldsymbol{\beta}^{2}$} & \multicolumn{2}{|c|}{ [A] } & \multicolumn{2}{|c|}{ [B] } \\
\hline & & & $R^{2}$ & $F$ & $R^{2}$ & $F$ \\
\hline $\begin{array}{l}\text { H10: The relationship between LMX and job performance is } \\
\text { moderated by autonomy. }\end{array}$ & $0.165^{*}$ & 0.031 & 0.027 & $6.197^{*}$ & 0.028 & 0.062 \\
\hline
\end{tabular}

$*, p \leq 0.05$.

LMX, leader member exchange.

and job performance is fully mediated by LMX. The total indirect effect was 0.024 , indicating that the indirect effect explained $2.4 \%$ of the variance in the total mediation model when taking the impact of the direct effect into consideration.

Hypothesis 5 predicted that the relationship between transformational leadership and LMX is mediated by emotional intelligence. The relationship between transformational leadership and LMX may be regarded as fully mediated because this relationship changed from a statistically significant relationship in step $1\left(\beta_{\mathrm{MLQ}}=0.16\right.$, $p<0.05)$ to a non-significant relationship in step 2 when the mediator variable emotional intelligence was included in the multiple regression equation $\left(\beta_{\mathrm{EQ}}=0.13, p>0.05\right)$. The total indirect effect was 0.08 , indicating that the indirect effect explained $8 \%$ of the variance in the total mediation model when taking the impact of the direct effect into consideration.

Hypothesis 7 predicted that the relationship between transformational leadership and job performance is mediated by emotional intelligence. In step $1\left(\beta_{\mathrm{MLQ}}=0.13, p<0.05\right)$, the relationship between transformational leadership and job performance changes from a significant relationship
$\left(\beta_{\mathrm{MLQ}}=0.13, p<0.05\right)$ to a non-significant relationship in step $2\left(\beta_{\mathrm{MLQ}}=0.02, p>0.05\right)$ when the mediator variable emotional intelligence was included in the multiple regression equation. This indicates that the relationship between transformational leadership and job performance is fully mediated by emotional intelligence. The total indirect effect was 0.12 , indicating that the indirect effect explained $12 \%$ of the variance in the total mediation model when taking the impact of the direct effect into consideration.

Finally, hierarchical moderated regression analysis was used to assess if autonomy moderates the relationship between LMX and job performance. Results from the moderated regression analysis are summarised in Table 7.

The moderated regression analysis suggests that the main effect between LMX and job performance was statistically significant $\left(\beta_{\text {LMX }}=0.165, p<0.05\right)$; however, the interaction term that was added in step 2 was unable to explain additional variance in the regression model that already contains the main effect. This result suggests that no support was found for Hypothesis 10 which suggests that autonomy does not moderate the relationship between LMX and job performance. 


\section{Discussion}

The present study set out to investigate the impact of transformational leadership on job performance through LMX relationships, emotional intelligence and autonomy. A model of the direct and indirect relationships between the variables was proposed and tested, in an effort to expand understanding of the mechanisms involved in the relationship between transformational leadership and job performance.

Support was found for most of the hypotheses. More specifically, statistical support was found for the relationships proposed by hypotheses $1,2,4,6,8,9$ and 11 .

Results from the study support the primary idea that transformational leadership on its own is not effective in shaping job performance. The current results suggest that the relationship between transformational leadership and job performance is shaped by pathways, namely LMX, emotional intelligence and autonomy. These findings are supported by research that implies that the relationship between transformational leadership and outcomes of interest is mostly facilitated by mediating mechanisms (Jyoti \& Bhau, 2015).

More specifically, support was found for the proposed relationship between transformational leadership and LMX $\left(\mathrm{H}_{2}\right)$. Literature suggests that transformational leadership is effective in fostering high-quality relationships between leaders and followers. Support was also found for the proposed relationship between transformational leadership and emotional intelligence $\left(\mathrm{H}_{4}\right)$.

A critical review of the literature demonstrated that the role of emotional intelligence in forming high-quality LMX relationships is not universally researched or acknowledged as a key attribute of transformational leadership. Results from the current study, however, found that emotional intelligence is a key ingredient in the TL-LMX sequence $\left(\mathrm{H}_{5}\right)$ (Clarke \& Mahadi, 2011).

A positive relationship was found between emotional intelligence and job performance $\left(\mathrm{H}_{6}\right)$. The current study looked at the propensity of emotional intelligence to regulate behaviour. Pekaar, Van der Linden, Bakker and Born (2017) found that when focusing on others' emotions, it is a good predictor of job performance within interpersonal contexts. However, the context remains an important aspect as it can determine whether there will be positive effects of emotional intelligence on job performance (Jordan, Dasborough, Daus, \& Ashkanasy, 2010). However, when all things held equal, emotional intelligence has been linked to higher job performance across a wide variety of jobs.

The links between LMX and job performance $\left(\mathrm{H}_{8}\right)$ and autonomy $\left(\mathrm{H}_{9}\right)$ were reviewed. Support was found for the proposed relationship between LMX and job performance, which is in line with previous literature (Chen, Lam, \& Zhong, 2007; Walumbwa, Cropanzano, \& Goldman, 2011).
Furthermore, the research by Chen et al. (2007) showed that LMX can also foster autonomy and psychological empowerment. This can permit followers to act autonomously once a strong LMX relationship has been established.

The transmission mechanism (i.e. mediating effects) of emotional intelligence and LMX in the context of transformational leadership and job performance presented full mediation. This is an important finding in placing a conditionality on leadership. More specifically, this finding suggests that transformational leadership is effective in driving follower performance through emotional intelligence and strong LMX relationships.

The implication of this finding is that emotional intelligence is a key ingredient in effective leadership and building meaningful relationships at work. Previous research supports the finding that emotional intelligence is considered an important contributor in explaining leadership effectiveness (Mayer, Salovey, \& Caruso, 2000), and it can be assumed that LMXs are inherently emotional exchanges (Lopes, Salovey, \& Strauss, 2003). At a time when the development of relationships between leaders and followers in organisations is seen as a non-essential, time-consuming activity (Jordan \& Troth, 2011), the results of the present study indicate the importance of the development of such relationships to improve job performance.

Finally, no support was found for Hypothesis 10 that stipulated that the relationship between LMX and job performance is moderated by autonomy. Results from the moderated regression analyses suggested that the interaction effect did not explain additional variance not explained by the main effect. This is in contradiction with existing empirical evidence that suggests job autonomy does play a moderating role in favourable workplace attitudes such as creativity and work involvement (Jaiswal \& Dhar, 2017; Volmer, Spurk, \& Niessen, 2012). Volmer et al. (2012) state that opportunities derived from high-quality social exchanges are optimised in combination with job autonomy, as it allows employees to decide the pace, series and approaches for carrying out their tasks. The contrary finding in the present study therefore warrants further exploration. One explanation may be that job performance was measured at the unit level, which may have influenced the results in explaining the nuanced relationship between the experiences of LMX, individual autonomy and unit-level performance.

\section{Managerial and practical implications}

Results from the study place the role of emotional intelligence at the core of strong leader member relationships and job performance. Implicitly, one would expect that transformational leaders make use of emotional intelligence to build high-quality relationships with followers; however, this relationship has not been tested formally in the applied setting. Voluminous research indicates that transformational 
leaders appeal and attempt to satisfy the emotional needs of followers to build trusting relationships (Alston \& Chin-Loy, 2016). However, recent research suggests that the mechanism between transformational leadership and job performance may be moderated and mediated by many interpersonal and contextual factors.

The results from the current study show that LMX and emotional intelligence are important mediators between transformational leaders and unit-level performance. Strong empirical support was found for the mediating role of emotional intelligence and high-quality relationships between transformational leadership and performance.

The practical implication of these findings suggests that organisations should select or develop leaders with high emotional intelligence competence because it is likely to lead to high-quality LMX relationships, which in turn will spill over to job performance. The same can be said for the mediating role of emotional intelligence between transformational leadership and high-quality LMX relationships. Although these relationships are to be expected, the current investigation explicitly modelled and tested the relationships. This will allow practitioners to use the current pattern of results as a blueprint to develop leadership strategies that may lead to high LMX relationships and unit-level performance.

In addition, the results suggest that emotional intelligence is the transmission mechanism that most leaders use to build high-quality relationships. The statistical results reveal that emotional intelligence of the leaders acts as the glue that facilitates the various social exchanges in the workplace between leaders and followers.

Lastly, the results indicate that job autonomy may play an important role as a direct effect on job performance but may not play an important moderating role between transformational leadership and job performance.

\section{Limitations and recommendations for future research}

Although results from the study are overwhelmingly positive, there are limitations to the study. One of the limitations of using a convenience sampling is that results cannot be generalised to the greater population (Jager, Putnick, \& Bornstein, 2017).

The sample was also relatively small in the study and from a single organisation. To test the robustness of the results one would have to replicate the study by using a different sample. Finally, mono-method bias may have an impact on the findings in the study because a single method of data collection was used. It is recommended that more diverse forms of data collection should be used in future (e.g. observation and diary entries) to overcome the single-method bias. A longitudinal study could be suggested in future research as a means of understanding causal relationships.
Furthermore, LMX is best measured in dyadic relationships, and therefore measurement at multiple levels is suggested for future studies (Clarke \& Mahadi, 2017).

\section{Conclusion}

This study aimed to conceptualise a model that depicted the relationship between transformational leadership, emotional intelligence, LMX and follower job performance in a selected organisation in the banking sector.

The research provided insight into the role of emotional intelligence in transformational leadership. The study further explored the effect of such leadership and the impact of social exchange at the leader member level.

Leadership has been found to play an important role in organisations, and specifically with the interaction between a leader and a member, what is known as the LMX relationship.

As LMX and emotional intelligence have been found to have a full mediating effect between transformational leadership and job performance, it ultimately creates an efficient working environment. Within this working environment, the employees' need for high-quality relationships with their leader can be fulfilled, without ignoring the tension to achieve organisational outcomes (i.e. performance) (Jordan \& Troth, 2011).

Goleman (1995) had emphasised that emotional intelligence will be an important factor in predicting personal and professional success. The results of this study show how emotional intelligence of leaders explains the performance success through the social exchange of the leader and followers.

\section{Acknowledgements}

The research organisation is acknowledged for providing access to participants.

\section{Competing interests}

The authors declared that no competing interests exist.

\section{Authors' contributions}

The article was conceptualised based on the master thesis research of M.W., the primary author. J.R.B. conducted the statistical analyses and wrote up the managerial implication, limitations and recommendations for future research. The authors' contributions should be recognised in the following sequence: M.W., J.R.B and M.D.P.

\section{Funding information}

This research received no specific grant from any funding agency in the public, commercial or not-for-profit sectors. 


\section{Data availability statement}

Data sharing is not possible because the partnering organisation has not provided permission to share the performance data of the respondents to anyone beyond the core research team.

\section{Disclaimer}

The views and opinions expressed in this article are those of the authors and do not necessarily reflect the official policy or position of any affiliated agency of the authors.

\section{References}

Aga, D.A. (2016). Transactional leadership and project success: The moderating role of goal clarity. Procedia Computer Science, 100, 517-525. https://doi.org/10.1016/j. procs.2016.09.190

Alabi, G., \& Alabi, J. (2014). Understanding the factors that influence leadership effectiveness of Deans in Ghana. Journal of Higher Education in Africa/Revue de l'enseignement supérieur en Afrique, 12(1), 111-132.

Alston, B.A., Dastoor, B., \& Chin-Loy, C. (2016). Emotional intelligence and transformational leadership to foster sustainability. International Journal of Business and Social Science, 7(5), 9-20.

Baron, R.M., \& Kenny, D. (1986). The moderator-mediator variable distinction in social psychological research: Conceptual, strategic, and statistical considerations. Journal of Personality and Social Psychology, 51(6), 1173-1182. https://doi. org/10.1037/0022-3514.51.6.1173

Bass, B.M. (1985). Leadership and performance beyond expectations. New York, NY: Free Press.

Bass, B.M. (1990). From transactional to transformational leadership: Learning to share the vision. Organizational Dynamics, 18(3), 19-31. https://doi.org/ 10.1016/0090-2616(90)90061-S

Bass, B.M., \& Avolio, B.J. (1992). Multifactor leadership questionnaire-short form 65. Binghamton, NY: Center for Leadership Studies.

Bass, B.M., \& Avolio, B.J. (1993). Improving organizational effectiveness through transformational leadership. Thousand Oaks, CA: Sage.

Chen, Z., Lam, W., \& Zhong, J.A. (2007). Leader-member exchange and member performance: A new look at individual-level negative feedback-seeking behavio and team-level empowerment climate. Journal of Applied Psychology, 92(1), 202. https://doi.org/10.1037/0021-9010.92.1.202

Cheung, Y.L., Connelly, J.T., Jiang, P., \& Limpaphayom, P. (2011). Does corporate governance predict future performance? Evidence from Hong Kong - Find Management, 40(1),159-197.https://doi.org/10.1111/j.1755-053X.2010.01138.x

Clarke, N., \& Mahadi, N. (2011). Chapter 9 emotional intelligence as a moderator of the quality of leader-Member exchange and work-related outcomes. In C. Hartel, N. Ashkanasy, \& W. Zerbe (Eds.). What have we learned? Ten years on (Vol. 7, pp. 227-254). Bingley: Emerald Group Publishing Limited.

Clarke, N., \& Mahadi, N. (2017). Differences between follower and dyadic measures of LMX as mediators of emotional intelligence and employee performance, wellbeing, and turnover intention. European Journal of Work and Organizationa Psychology, 26(3), 373-384. https://doi.org/10.1080/1359432X.2016.1263185

Cleavenger, D.J., \& Munyon, T.P. (2013). It's how you frame it: Transformational leadership and the meaning of work. Business Horizons, 56(3), 351-360. https:// doi.org/10.1016/j.bushor.2013.01.002

Cronbach, L.J. (1951). Coefficient alpha and the internal structure of tests. Psychometrika, 16, 297-334. https://doi.org/10.1007/BF02310555

Dansereau, F., Graen, G., \& Haga, W.J. (1975). A vertical dyad linkage approach to leadership within formal organizations: A longitudinal investigation of the role making process. Organizational Behaviour \& Human Performance, 13(1), 46-78. https://doi.org/10.1016/0030-5073(75)90005-7

Dienesch, R.M., \& Liden, R.C. (1986). Leader-member exchange model of leadership: A critique and further development. The Academy of Management Review, 11(3), 618-634. https://doi.org/10.5465/amr.1986.4306242

Ducket, H., \& Macfarlane, E. (2003). Emotional intelligence and transformationa leadership in retailing. Leadership \& Organization Development Journal, 24(6) 309-317. https://doi.org/10.1108/01437730310494284

Dunegan, K.J., Uhl-Bien, M., \& Duchon, D. (2002). LMX and subordinate performance: The moderating effects of task characteristics. Journal of Business and Psychology, 17(2), 275-285. https://doi.org/10.1023/A:1019641700724

Gardner, W.L., Lowe, K.B., Moss, T.W., Mahoney, K.T., \& Cogliser, C.C. (2010). Scholarly leadership of the study of leadership: A review of The Leadership Quarterly's second decade, 2000-2009. The Leadership Quarterly, 21(6), 922-958. https:// doi.org/10.1016/j.leaqua.2010.10.003

George, J.M. (2000). Emotions and leadership: The role of emotional intelligence Human Relations, 53(8), 1027-1055. https://doi.org/10.1177/0018726700538001

Gignac, G.E. (2008). Genos emotional intelligence inventory technical manual. Sydney: Genos Press.

Goleman, D. (1995). Emotional intelligence. New York, NY: Bantam Books.

Goleman, D. (2001). Emotional intelligence: Perspectives on a theory of performance. In C. Cherniss \& D. Goleman (Eds.), The emotionally intelligent workplace (pp. 27-44). San Francisco, CA: Jossey-Bass.
Graen, G.B., \& Uhl-Bien, M. (1995). Relationship-based approach to leadership: Development of Leader-Member Exchange (LMX) theory of leadership over 25 years: Applying a multi-level multi-domain perspective. Leadership Quarterly, years: Applying a multi-level multi-domain perspective. Leader

Hackman, J.R., \& Lawler, E.E. (1971). Employee reactions to job characteristics. Journa of Applied Psychology, 55(3), 259. https://doi.org/10.1037/h0031152

Hackman, J.R., \& Oldham, G.R. (1975). Development of the job diagnostic survey. Journal of Applied Psychology, 60(2), 159. https://doi.org/10.1037/h0076546

Hood, M., Conlon, E., \& Andrews, G. (2008). Preschool home literacy practices and children's literacy development: A longitudinal analysis. Journal of Educational Psychology, 100, 252-271. https://doi.org/10.1037/0022-0663.100.2.252

Jager, J., Putnick, D.L., \& Bornstein, M.H. (2017). II. More than just convenient: The scientific merits of homogeneous convenience samples. Monographs of the Society for Research in Child Development, 82(2), 13-30.

Jaiswal, D., \& Dhar, R.L. (2017). Impact of human resources practices on employee creativity in the hotel industry: The impact of job autonomy. Journal of Human Resources in Hospitality \& Tourism, 16(1), 1-21. https://doi.org/10.1080/153328 45.2016.1202035

Jiang, W., Zhao, X., \& Ni, J. (2017). The impact of transformational leadership on employee sustainable performance: The mediating role of organizationa citizenship behavior. Sustainability, 9(9), 1567. https://doi.org/10.3390/ su9091567

Jordan, P.J., Dasborough, M.T., Daus, C.S., \& Ashkanasy, N.M. (2010). A call to context Industrial and Organizational Psychology, 3(2), 145-148.

Jordan, P.J., \& Troth, A. (2011). Emotional intelligence and leader member exchange: The relationship with employee turnover intentions and job satisfaction Leadership \& Organization Development Journal, 32(3), 260-280. https://doi. org/10.1108/01437731111123915

Jyoti, J., \& Bhau, S. (2015). Impact of transformational leadership on job performance: Mediating role of leader-member exchange and relational performance: Mediating role of leader-member exchange and relational 2158244015612518

Kenny, D.A., Kashy, D., \& Bolger, N. (1998). Data analysis in social psychology. In D. Gilbert, S. Fiske, \& G. Lindzey (Eds.), Handbook of social psychology (4th ed., pp. 233-265). New York: McGraw-Hill.

Kim, T.Y., Liu, Z., \& Diefendorff, J.M. (2015). Leader-member exchange and job performance: The effects of taking charge and organizational tenure. Journal of Organizational Behavior, 36(2), 216-231. https://doi.org/10.1002/job.1971

Kirkbride, P. (2006). Developing transformational leaders: The full range leadership model in action. Industrial and Commercial Training, 38(1), 23-32. https://doi. org/10.1108/00197850610646016

Krishnan, V.R. (2005). Leader-member exchange, transformational leadership, and value system. Electronic Journal of Business Ethics and Organization Studies, $10(1), 14-21$

Li, C.K., \& Hung, C.H. (2009). The influence of transformational leadership on workplace relationships and job performance. Social Behavior and Personality 37(8), 1129-1142. https://doi.org/10.2224/sbp.2009.37.8.1129

Liden, R.C., Sparrowe, R.T., \& Wayne, S.J. (1997). Leader-member exchange theory: The past and potential for the future. Research in Personnel and Human Resources Management, 15, 47-120.

Lopes, P.N., Salovey, P., \& Straus, R. (2003). Emotional intelligence, personality, and the perceived quality of social relationships. Personality and Individual Differences, 35(3), 641-658. https://doi.org/10.1016/S0191-8869(02)00242-8

Lowe, K.B., \& Gardner, W.L. (2001). Ten years of the leadership quarterly: Contributions and challenges for the future. The Leadership Quarterly, 11(4), 648-657. https:// doi.org/10.1016/S1048-9843(00)00059-X

Maslyn, J., \& Uhl-Bien. (2001). Leader-member exchange and its dimensions: Effects of self-effort and other's effort on relationship quality. The Journal of Applied Psychology, 86(4), 697-708. https://doi.org/10.1037/0021-9010.86.4.697

Mayer, J.D., \& Salovey, P. (1997). What is emotional intelligence? In P. Salovey \& D. Sluyter (Eds.), Emotional development and emotional intelligence: Implication for educators (pp. 3-31). New York, NY: Basic Books.

Mayer, J.D., Salovey, P., \& Caruso, D. (2000). Models of emotional intelligence. In R.J. Sternberg (Ed.), The handbook of intelligence (pp. 396-420). New York: Cambridge University Press.

Morgeson, F.P., \& Humphrey, S.E. (2006). The work design questionnaire (WDQ): Developing and validating a comprehensive measure for assessing job design and the nature of work. Journal of Applied Psychology, 91(6), 1321-1339. https://doi. org/10.1037/0021-9010.91.6.1321

Northouse, P.G. (2001). Leadership: Theory and practice (2nd edn.). Thousand Oaks, CA: Sage.

Northouse, P.G. (2016). Leadership: Theory and practice (7th edn.). Thousand Oaks, CA: Sage.

Palmer, B., \& Stough, C. (2001). Workplace SUEIT: Swinburne university emotional intelligence test-descriptive report. Melbourne: Organisational Psychology Research Unit, Swinburne University.

Pekaar, K.A., Van der Linden, D., Bakker, A.B., \& Born, M.P. (2017). Emotional intelligence and job performance: The role of enactment and focus on others' emotions. Human Performance, 30 (2-3), 135-153. https://doi.org/10.1080/0895 9285.2017.1332630

Pillay, M., Viviers, R., \& Mayer, C. (2013). The relationship between emotional intelligence and leadership styles in the South African petrochemical industry. SA Journal of Industrial Psychology, 39(1), 1-12. https://doi.org/10.4102/sajip.v39i1.1109 
Rose, S., Spinks, N., \& Canhoto, A.I. (2014). Management research: Applying the principles. New York: Routledge.

Setley, D.M., Dion, P., \& Miller, J. (2013). Do various styles of leadership significantly relate to a subordinate's perceived relationship with his leader? International Journal of Human Resource Studies, 4(21), 1-10.

Shrout, P.E., \& Bolger, N. (2002). Mediation in experimental and nonexperimental studies: New procedures and recommendations. Psychological Methods, 7(4), 422. https://doi.org/10.1037/1082-989X.7.4.42

Tabachnick, B.G., \& Fidell, L.S. (2007). Using multivariate statistics (5th edn.). New York, NY: Allyn and Bacon.

Volmer, J., Spurk, D., \& Niessen, C. (2012). Leader-member exchange (LMX), job autonomy, and creative work involvement. The Leadership Quarterly, 23(3), 456-465. https://doi.org/10.1016/j.leaqua.2011.10.005
Walumbwa, F.O., Cropanzano, R., \& Goldman, B.M. (2011). How leader-member exchange influences effective work behaviors: Social exchange and internalexternal efficacy persectives. Personnel Psychology, 64(3), 739-770. https://doi. org/10.1111/j.1744-6570.2011.01224.x

Wang, G., Oh, I.S., Courtright, S.H., \& Colbert, A.E. (2011). Transformational leadership and performance across criteria and levels: A meta-analytic review of 25 years of research. Group \& Organization Management, 36(2), 223-270. https://doi. org/10.1177/1059601111401017

Welch, J. (2003). The best teams are emotionally literate. Industrial and Commercia Training, 35(4), 168-170. https://doi.org/10.1108/00197850310479169

Yammarino, F.J. (1994). Indirect leadership: Transformational leadership at a distance. In B.M. Bass, \& B.J. Avolio (Eds.), Improving organizational effectiveness through transformational leadership (p. 26-47). Thousand Oaks, CA: Sage Publications, Inc. 